\title{
For Web Software Company-A Micro Company But a Global Business
}

\author{
Ruiyi $\mathrm{Li}^{1, *}$, Sun $\mathrm{Yi}^{2}$ \\ ${ }^{1}$ New Channel school, Fuzhou, 350025, China \\ ${ }^{2}$ Guangdong experimental high school, Guangzhou, 510375, China \\ *Corresponding author. Email: 734668451@qq.com
}

\begin{abstract}
This paper mainly discusses the potential basis and feasible development direction of new Internet companies in the globalization age. For dealing with this, we first apply some business assessment statement to conduct various evaluations of the company and proposed a plan to compete directly in the global market, passing the lengthy domestic development stage by cooperating with universities as a springboard. We implement the framework based on VRINO, SMART GOAL statement and so on to demonstrate the feasibility of it. This paper can provide guidance for the initial development direction and long-term goals of network technology companies in the information age.
\end{abstract}

Keywords: PESTLE statement, Porter's 5F, SWOT, Globalization, Mission and Vision.

\section{INTRODUCTION}

In this work, we have revealed an underlying business strategy and development guidance of network technology, this strategy and guidance is demonstrated by classic business model. The suggestions are focus on some newborn opportunities and develop a solution for company to avoid unnecessary competitions and obtain more market share.

The business case we use as a general model is company called Forweb [1]. Refer to Figure 1, which shows the geographical location of the company. It is obvious that the company did not have a ideal geographical condition since it was set up on a small island in Atlantic Ocean, Madeira. However, the globalization reduced the cost of communication, in other words, technical efficiency have been gain though globalization which has made cheaper to transport goods on foreign countries. Therefore, the Forweb company was succeeded by using the appropriate strategy and stick with every change of the world.

\section{Initial challenges:}

(i) The difficulties of expanding their business.

(ii) The current model of the product is not conductive to develop globally. Because the insufficient language versions contrary to the overall business strategy of operating in the world market.

(iii) The company was entirely dependent on one product.

The company was initially focused on the born global strategy, which helped it to skip the period of domestic development. Born Global is an accelerator program for ambitious companies that aspire to go global. Selected companies are guided towards a verified business model.

By considering the case of Forweb company, there are some latent chance that have not been discovered. Thus, In this work, we chiefly study the new relationship between buyer and supplier, how to utilize the advantage of the company in the global competition and new pathway of attracting customers. 


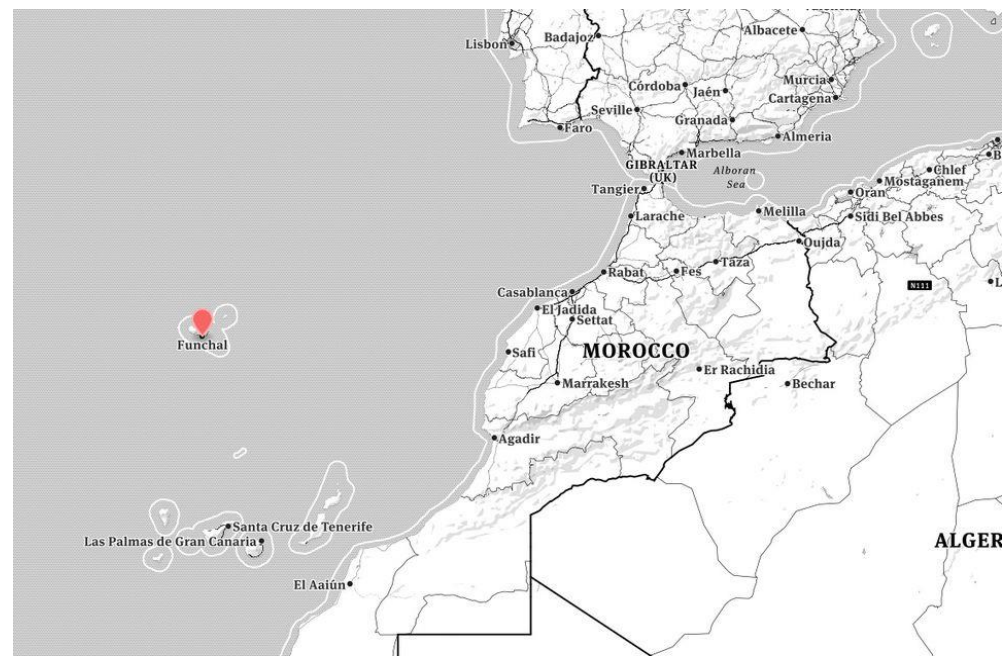

Figure 1 the initial geographical location of Forweb [2]

\section{STRATEGY ANALYSIS}

\section{(1) Mission and Vision Statement:}

\subsection{Mission}

The mission of the company is to creating user centered Web applications by offering a service that can analyse and collect data for professors and students.

Vision: Become a global business and focus on niche market.

\subsection{Proposed business strategy:}

Making contract with universities all over the world. So the product can be advertised to professors, students and researchers who need AI calculation or questionnaires.

\subsection{The SWOT Statement}

\subsubsection{STRENGTH:}

The business that has gained significant competitive advantage from having selling opportunities in several countries.

Software has developed customized solutions for clients who visit the "Question Form" website.

\subsubsection{WEAKNESS:}

The company initially set up on a small island so that it has limited scale of local market.

The current business model will be inappropriate as the company expands it scale.

The company is entirely relies on one product.

Need to collaborate with large companies or universities in other countries to develop the product.

\subsubsection{OPPORTUNITY:}

The globalization creates opportunity for the company to search partner from worldwide.

Use partnerships or information technology as a means of disseminating their products or services.

Expanding the geographical reach of a company is now much easier not only because of the effect of internet globalization, but also because of improved ways of managing business at a distance.

\subsubsection{THREAT:}

The competition in this industry is fierce, making it difficult for small companies to survive and gain a foothold.

The company current only has one product, it may sink into mediocrity if it is not innovative.

\subsection{The PESTLE Statement:}

POLITICAL: The current increase in globalization and technology provides convenience for the cooperation of multinational companies and creates more entrepreneurial opportunities for third-party data service software.

ECONOMIC: In 2008, the world has entered the stage of globalization, and the current economic situation of global cooperation has created an increasing demand for software for efficient analysis and data collection.

SOCIOCULYTURAL: Globalization helps people to know foreign cultures better, and consumers are willing to consume on a global scale. In order to maximize profits, enterprises' remote management technology needs to have more efficient data collection and analysis capabilities. 
TECHNOLOGY: After entering the information age, the rapid development of network technology enables the company to constantly update and improve its own system to meet the needs of customers.

LEGAL: The company is a software company dedicated to improving data collection and analysis services, and it is unlikely that normal business operations would violate the law.; global patent protection is good for us

ENVIRONMENTAL: As an Internet company, there is no pollution that can be caused.

\subsection{How to market and sell the service:}

Considering that this software has the ability of data analysis and collection, we can also promote this software to universities in various countries, using it as a springboard to expand our business to the whole world.

\subsection{Porter's five force:}

Threat of entry: There is basically no barrier to entry in this field, and people will continue to join the market. Therefore, it does not really matter if there are new firms enter the market since the competition is already strong.

Bargaining power of supplier: Because Forweb is now in a period of development, constant updates and upgrades are the only way to attract users. Both updates and upgrades require technical and technical knowledge.

Bargaining power of buyer: Compared with the actual industry, the fee of the virtual industry will be more fixed. Therefore, the buyer's bargaining power will also be greatly reduced. But the price should not be too high, it is best to make customers feel that it is cheap.

The Threat of Substitute: The technology of Forweb is protected by patent right. Thus, the threat of substitute is low.

Rivalry: It is necessary for Forweb to differentiate its product with other firms to attract users in a such competitive company.

\subsection{The VRINO statement:}

Value: It allows users who are unfamiliar with the technology to easily build an online survey and then to both collect and analyse the data.

Rarity: The product is the only product that dose not require user have high technical skills.

Immutability The technology of the company is protected by patent right so that it is difficult for other companies to imitate.

Non-substitutable: There are lots of firms in this field that producing similar products which are close substitutes, its market power is likely to be relatively weak.

Organization: The company was founded by a freelancer, so far the company does not have a complete management system. This puts them at a disadvantage in terms of resource management.

\subsection{The SMART goal:}

Specific: The company will cooperate with universities and institutions to expand my business.

Measurable: Within one year, the company need to make contract with at least 10 universities and then 100 in one decade.

Attainable: Making contacts with 10 universities in one year and 100 in ten years is achievable and realistic.

Relevant: Adding additional clients to my business will allow me to grow my business and increase my revenue.

Time-bound: All these targets need to be done within 3 years. (Except the 100 contracts with universities.

\subsection{Innovation and Differentiation Initiatives and Processes:}

In 2007, the company found an opportunity: at that point, most of web are charged for certain price so that the Forweb company was the first company to make their product free for first use. This innovative action helps the Forweb company developed a bunch of customers.

After 6 month of developing and testing, the Web 2.0 came in to being. It allows users who are unfamiliar with the technology to easily build an online survey and then to both collect and analyse the data.

From then on, this product became more and more competitive in the market, this laid the foundation for the company's future success.

\subsection{Key Capabilities and Core Competencies:}

One capabilities of the company is that it allows users to organize their own surveys and publish them on social media.

The AI calculator will record all the results.

All steps are done by AI automatically.

Does not require high technical skill.

\subsection{Business model canvas:}

Refer to Figure 2, the business model can canvas reveals the design of a business and make it unique to 
compete in the market. In this section, we mainly enhanced the importance of AI computing power. The reason why we did this is that in order to make the company competitive in the market, the characteristics must be obvious. Because this is the base of how to create accurate business positioning and find the right target group.

\begin{tabular}{|c|c|c|c|c|c|}
\hline $\begin{array}{l}\text { Key Partners } \\
\text { University with } \\
\text { students and } \\
\text { professors from } \\
\text { all over the world. }\end{array}$ & $\begin{array}{l}\text { Key Activities } \\
\text { Develop an } \\
\text { software service } \\
\text { which helps people } \\
\text { collect and analyse } \\
\text { data }\end{array}$ & \multicolumn{3}{|c|}{ 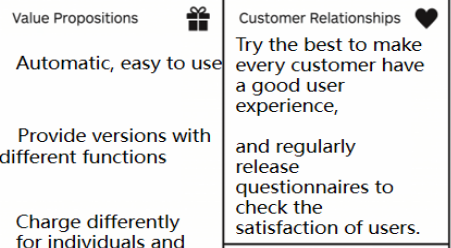 } & $\begin{array}{l}\text { Students and } \\
\text { professors in } \\
\text { universities }\end{array}$ \\
\hline $\begin{array}{l}\quad \text { Companies } \\
\text { who are } \\
\text { developing } \\
\text { artificial } \\
\text { intelliengence. }\end{array}$ & $\begin{array}{l}\text { Key Resources } \\
\text { A perfect } \\
\text { international } \\
\text { language system. } \\
\text { Strong Al } \\
\text { computing power }\end{array}$ & & & $\begin{array}{l}\text { Channels } \\
\text { Advertising the } \\
\text { software to } \\
\text { students in } \\
\text { university so that } \\
\text { they advertise } \\
\text { the web when } \\
\text { they graduated } \\
\text { and back to } \\
\text { hometown }\end{array}$ & $\begin{array}{l}\text { People who need } \\
\text { to make a } \\
\text { questionnaire and } \\
\text { statistical results }\end{array}$ \\
\hline $\begin{array}{l}\text { st Structure } \\
\text { As an Internet } c \\
\text { has relatively low } \mathrm{f} \\
\text { cost. }\end{array}$ & $\begin{array}{l}\text { any, this company } \\
\text { st and variable }\end{array}$ & & $\begin{array}{l}\text { Revenue Strean } \\
\text { There ar } \\
\text { to be pa } \\
\text { of indivic } \\
\text { paid ver } \\
\text { supporte }\end{array}$ & $\begin{array}{l}\text { e some specific ver } \\
\text { id. By conclusion, } \\
\text { dual and companie } \\
\text { sion (with more } \\
\text { ed. }\end{array}$ & $\begin{array}{l}\text { Is that needs } \\
\text { ut over } 80 \% \\
\text { ill choose the } \\
\text { ions }\end{array}$ \\
\hline
\end{tabular}

Figure 2 The business model canvas [3]

\subsection{The Charge model}

Refer to Figure 3 the charge model is separated into business use and individual use. By considering the difference in financial ability between individual and firms, we propose businesses to use the pricing strategy of price discrimination (refer to Figure 4, the company can gain $\mathrm{ABEG}$ of consumer surplus from consumer by price discriminating, selling $\mathrm{OK}$ output to those consumer prepared to pay a minimum $\mathrm{OB}$, and selling $\mathrm{KH}$ to other consumers only prepared to pay a minimum OA.), which increase the consumer surplus.*

*A consumer surplus happens when the price that consumers pay for a product or service is less than the price they're willing to pay.

\section{Charge model}

\begin{tabular}{|c|c|}
\hline Individual use & Business use \\
\hline $\begin{array}{l}\$ 30 / \text { month or } \$ 10 / \text { use } \\
\text { BILLED \$299 IF PAID ANNUALLY }\end{array}$ & $\begin{array}{c}\$ 165 / \text { month } \\
\text { BILLED } \$ 1899 \text { IF PAID ANNUALLY }\end{array}$ \\
\hline - Unlimited number of surveys & $\begin{array}{l}\text { - Unlimited number of } \\
\text { surveys }\end{array}$ \\
\hline - Unlimited questions per survey & $\begin{array}{l}\text { - Unlimited questions per } \\
\text { survey }\end{array}$ \\
\hline $\begin{array}{l}\text { - } 8000 \text { responses per month } \\
\text { - Skip advertisements }\end{array}$ & $\begin{array}{l}\text { - } 800000 \text { responses per } \\
\text { month }\end{array}$ \\
\hline - Automatic statistics & $\begin{array}{l}\text { - With fine control over who } \\
\text { can view and edit }\end{array}$ \\
\hline NOTE: BOTH VERSIONS ARE FREE & - Skip advertisements \\
\hline FOR FIRST USE & - Data export \\
\hline & - Automatic statistics \\
\hline
\end{tabular}

Figure 3 The charge model of the software [4]

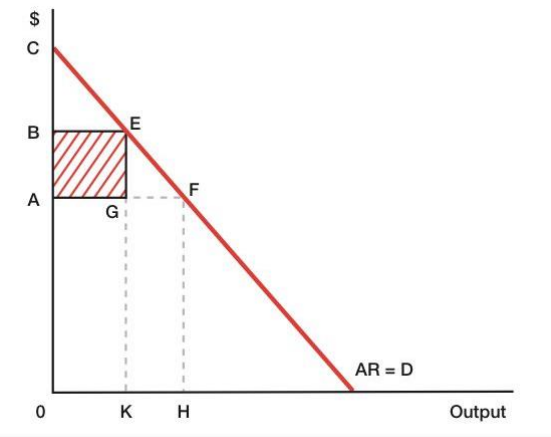

Figure $\overline{4 \text { The diagram illustration of significant }}$ of price discrimination [5]

\section{SUPPORTING ELEMENTS}

\subsection{The Alliances:}

Supplier side: Contract with universities to give them the right to use the software at a relatively low price.

Consumer side: Inviting students, professors, and researcher there to sign for the Forweb company so that they receive discount when using the product.

\subsection{The Organizational chart:}

Refer to Figure 5, the organizational structure is divided in four parts. The first three section are the general ones, however, we strongly advise that making innovation sector a special one, which directly reports to the general manager. Because especially for network companies, the technology is updating rapidly, make innovation sector supervised by the manager ensure the 
company will not date.

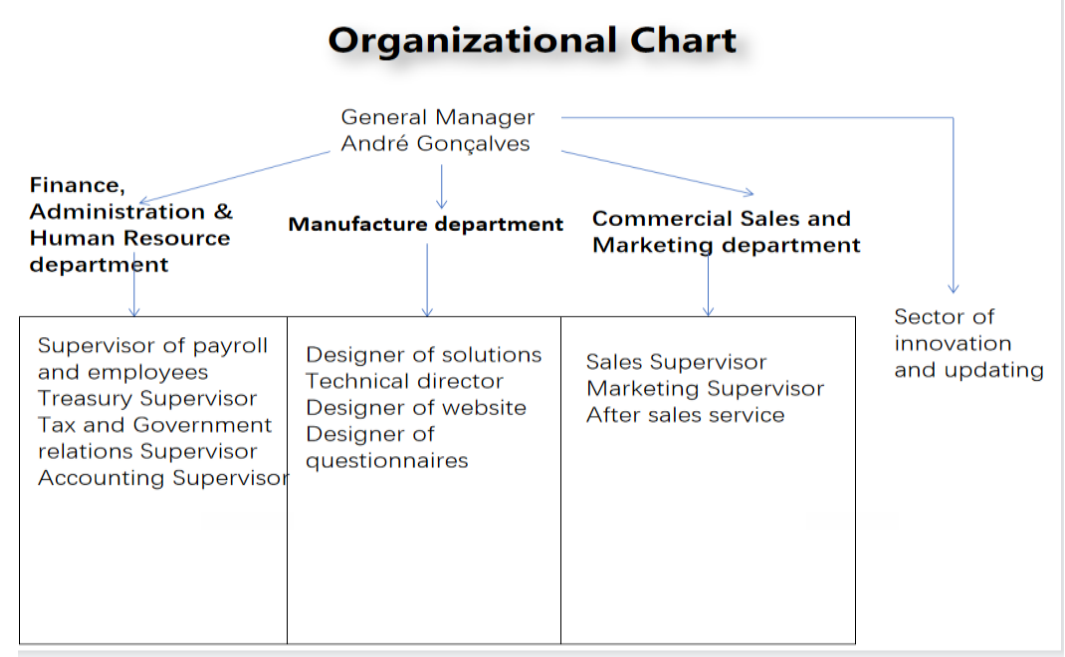

Figure 5 The organizational chart of the company

\subsection{Outline of a Key Innovation Process:}

According to Figure 6, we can tell that the company maintained a constant updating rate.

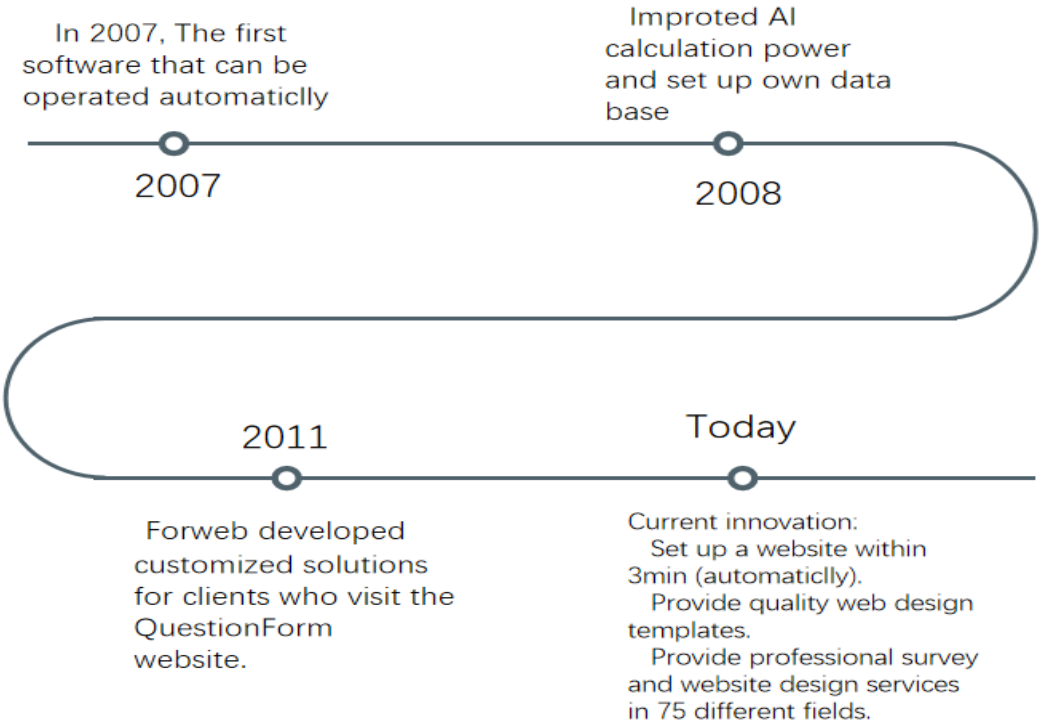

Figure 6 The outline of the key innovation process [6]

\subsection{Market research:}

Market characteristics: Strong competition in the market. However, no firms is seeking for cooperation with universities so far

Biggest competitor: "Survey Monkey" supports 17 languages and 28 currencies. Currently, its domestic U.S. market accounts for 55\% [6] of the company's business.
The amount of demand in the market: The amount of people in universities and institutions grew from 68.6 million to 110 million within one decade. Therefore, the demand in institutions and universities of using AI calculating and analyzing is definitely surging up

In addition, the amount of people who have access to the Internet increased dramatically.

The effect of information age and globalization (Market research): 


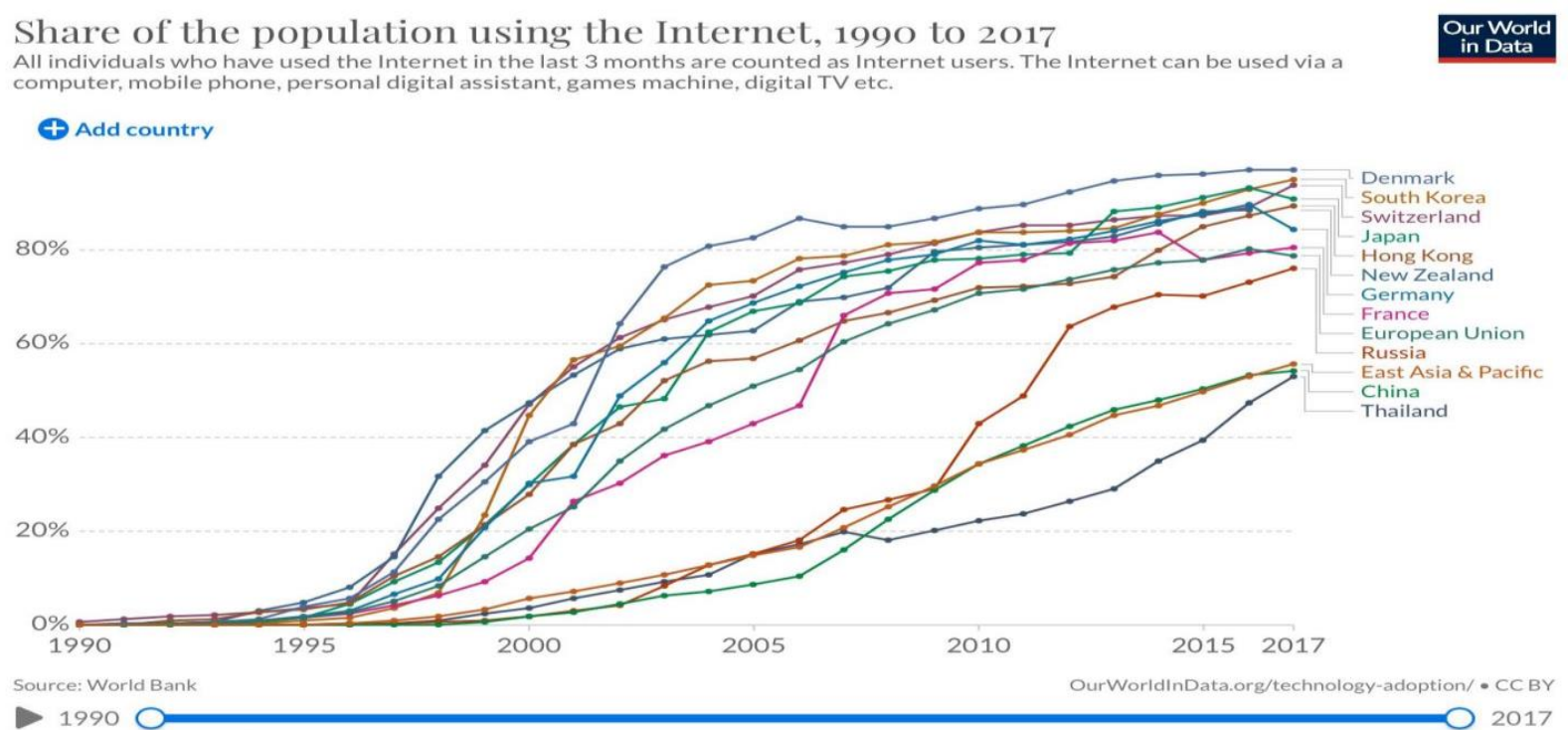

Figure 7 The share of population using the Internet [7]

According to Figure 7 most of counties experienced a significant growth in the share of population using the Internet in this globalization age, it is a wonderful chance for newborn network companies to develop.

\section{CONCLUSION}

The effect of globalization can increase both actual growth and potential growth of a company. The breakdown of the Soviet system and opening up of China towards a more market base business environment [8]. So the network company is particular benefited because their output is driven by export service and the cost of communication is reduced dramatically by globalization (Efficient communications technology and lower customs barriers).

In addition, the globalization also reduced the immobility of workers, because the fees and time taken for distance travel is decreased by modern transportation system [9]. That means the company can recruit high skill workers from wider range of the world. Alternatively, large companies can directly set up subsidiary companies in developing countries (ex. China and India), these counties have relatively low wage rate.

However, although the globalization bring us lots of business opportunities, it also conducts some risks and negative externalities. For instance, the competition also become ever global, both buyers and other sellers have more information about the product, this makes prices more transparent and cause stronger competition. Furthermore, the political environment also becomes unpredictable, some countries may adopt protectionist to prevent the foreign business invasion.

In such a complicate situation, this paper is aim to produce a solution and strategy which can increase the survival rate of network company and guide them to earn more market share.

\section{ACKNOWLEDGMENT}

This work was guided by summer Entrepreneurship and innovation project, taught by Professor Lin Giralt (Rice university school of business ) and teaching assistant Zhiqing Wang.

\section{REFERENCES}

[1] Alejandro Garcia Berra, Alicia Bolivar Cruz, Carmen Inés Ruiz de la Rosa, Carlos Fernández Hernández, Carolina Malheiro, Daniel Pavlov, Desiderio Gutiérrez Taño, Emanuele Sandri, Emilio Paolucci, Ewa Helienek, Francisco J. García Rodríguez, Kostas Galanakis, Leo Italiano, Lorela Corbeanu, Lucía Dobarro Delgado, M. Pino Medina Brito, Manuel González de la Rosa, Maya Hoveskog, Michelle Perello, Milena Marinova, Milena Kirova, Nádia Lemos, Panikkos Poutziouris, Paraskevi Gkiourka, Rosa M. Batista Canino, Sandy Nascimento, Skevos Evripidou, Svilen Kunev, Timea Czirner Svilen Kunev, Kostas Galanakis, Paraskevi Gkiourka. (2011) Case Study Book Entrepreneurship and Innovation \& Business creation and management Publisher: Ruse University page 56-59.

[2] James Martin Ita. (2019) Travel to the Madeira Islands Madeira Island Location Map and Travel Guide (tripsavvy.com)

[3] The table of business model canvas was downloaded from: Michiel (2020) https://www.courante.nl/

[4] The inspiration of charge model was from: https://www.surveymonkey.com/pricing/?ut_source $=$ homepage\&ut_source $3=$ megamenu

[5] Karen Borrington, Tracey Joad (2019) Pearson 
Edexcel International A Level Economic student book2 Published by Pearson Education Limited, 0 Strand, London, page 101

[6] Data fromhttp://www.forweb.vip/

[7] Data from: Survey Monkey https://www.surveymonkey.com/mp/enterprise/?ut_ source=megamenu

[8] Data from: Our World In Data (2017) https://ourworldindata.org/grapher/share-with-drug -use-disorders? tab $=$ chart

[9] Karen Borrington, Tracey Joad (2019) Pearson Edexcel International A Level Economic student book2 Published by Pearson Education Limited,0 Strand, London, page 157-167 